\title{
Rootstock Effects on Almond Leaf Scorch Disease Incidence and Severity
}

\author{
R. Krugner and C. A. Ledbetter, USDA-Agricultural Research Service, San Joaquin Valley Agricultural Sciences Center, 9611 South \\ Riverbend Avenue, Parlier, CA 93648
}

\begin{abstract}
Krugner, R., and Ledbetter, C. A. 2016. Rootstock effects on almond leaf scorch disease incidence and severity. Plant Dis. 100:1617-1621.

A 5-year field study was conducted to evaluate effects of duration and exclusion of Xylella fastidiosa infections on young almond tree performance and their links to tree vigor. 'Nemaguard,' 'Okinawa,' 'Nonpareil,' and Y119 were used as rootstocks for almond scion 'Sonora.' Among $X$. fastidiosa-infected trees, there was significant etiological heterogeneity with i) absence of leaf scorching symptoms in the presence of reduced growth, ii) presence of leaf scorching symptoms in the absence of reduced growth, and iii) severe leaf scorching and reduced growth. Trunk cross sectional areas of $X$. fastidiosa-infected trees grafted on 'Nemaguard' and 'Nonpareil' rootstocks were significantly smaller than noninfected trees,

whereas trunk size of trees grafted on 'Okinawa' and Y119 was not affected by infection status. Severity of leaf scorching symptoms was highest on trees grafted on 'Nonpareil' rootstock, intermediate on 'Okinawa' and Y119, and lowest on 'Nemaguard.' $X$. fastidiosa infections and seasonal leaf scorching symptoms persisted on most inoculated trees throughout the study, except on trees grafted on 'Nemaguard' that manifested complete leaf scorching symptom remission and apparent elimination of the pathogen after the second year. Results indicate that depending on rootstock type $X$. fastidiosa can affect trunk size in a relatively short period and/or persist for years as trees grow.
\end{abstract}

California is the sole producer of almonds in the United States, with yearly revenue of $\$ 6.4$ billion (CDFA 2015). The vast majority of the 412,000 ha of almond orchards in California are located in the San Joaquin Valley (CDFA 2015), where significant heterogeneity of disease incidence and severity exists among regions and cultivars affected by almond leaf scorch disease (ALSD) (Cao et al. 2011; Ledbetter and Rogers 2009; Sisterson et al. 2008, 2012; Wilhelm et al. 2011). The disease is caused by the xylem-limited bacterium Xylella fastidiosa Wells et al. (Davis et al. 1980), which is transmitted by several species of sharpshooters and spittlebugs (Mircetich et al. 1976; Purcell 1980) or the use of infected budwood (Boyhan et al. 1996; Hutchins et al. 1953; Mircetich et al. 1976).

ALSD was first noted in California in the early 1950s (Mircetich et al. 1976). In 1974, the disease was reported from 14 different counties throughout California affecting $50 \%$ of the trees in some locations (Sanborn et al. 1974). Recent surveys showed that ALSD persists in almond production areas of California with incidence in affected orchards ranging from 0.08 to $17 \%$ depending on region and cultivar (Cao et al. 2011; Daane et al. 2011; Sisterson et al. 2012). In central California, $X$. fastidiosa-infected trees remain asymptomatic from bloom (February to March) to the end of kernel enlargement (June). Symptoms of ALSD appear and progress rapidly during the period of hull split (July to early August) and persist until leaf senescence. Although most of the tree growth, fruit set, and nut maturation occurs during asymptomatic (i.e., absence of leaf scorching) stages of disease progression, yield of ALSD-affected trees can be reduced by 20 to $40 \%$ compared with nonaffected trees, depending on cultivar (Sisterson et al. 2012).

The host range of $X$. fastidiosa is broad. As a result, $X$. fastidiosa causes disease in a wide array of crops other than almond. In

Corresponding author: R. Krugner; E-mail: Rodrigo.Krugner@ars.usda.gov

Mention of trade names or commercial products in this publication is solely for the purpose of providing specific information and does not imply recommendation or endorsement by the U.S. Department of Agriculture. USDA is an equal opportunity provider and employer.

Accepted for publication 28 February 2016.

http://dx.doi.org/10.1094/PDIS-01-16-0125-RE

This article is in the public domain and not copyrightable. It may be freely reprinted with customary crediting of the source. The American Phytopathological Society, 2016.
California, most of the information available on $X$. fastidios $a$ comes from studies on grapevines, where it causes Pierce's disease (Davis et al. 1978). Studies with grapevines determined that growth and survival of $X$. fastidiosa was affected by exposure of infected plants to low temperatures, resulting in a "cold curing" phenomenon characterized by remission of symptoms and elimination of the pathogen (Feil and Purcell 2001; Lieth et al. 2011). Similarly, ALSD is characterized by the possibility of curing the disease with natural low winter temperatures (Cao et al. 2013; Ledbetter et al. 2009). Although it is clear that the intensity of the ALSD winter curing phenomenon varies according to the date of bacterial inoculation and type of scion (Cao et al. 2011; Ledbetter et al. 2009), little is known about long-term rootstock effects on ALSD incidence and severity, especially as it relates to the winter curing phenomenon. Therefore, the objective of this study was to exploit rootstock resistance to $X$. fastidiosa to confine bacteria above the graft union and thereby intensify overwintering mortality of populations in above-ground plant parts.

\section{Materials and Methods}

Establishment of almond trees. Almond trees were established at the USDA-ARS San Joaquin Valley Agricultural Sciences Center (SJVASC) in Parlier, CA, to evaluate the effects of different rootstocks on ALSD progression and intensity. In late November 2009, approximately 100 seeds each of peach 'Nemaguard' (Prunus persica (L.) Batsch $\times P$. davidiana (Carr.) Franch) and 'Okinawa' (P. persica), almond 'Nonpareil' ( $P$. dulcis (Mill.) D.A. Webb), and the peach-almond hybrid accession Y119 (Ledbetter and Sisterson 2008) were planted $15 \mathrm{~cm}$ apart in rows within large field cages ( $3 \mathrm{~m}$ width $\times 1.8 \mathrm{~m}$ height $\times 11 \mathrm{~m}$ length), and used as rootstocks for almond scion 'Sonora.' 'Nemaguard' is ALSD-resistant (Krugner et al. 2012; Ledbetter and Rogers 2009) and the most common Prunus rootstock used in California for both stone fruits and almonds (Reighard and Loreti 2008). 'Okinawa' is a low-chill requirement seed-propagated rootstock that has never been commercially adopted in California. While similar to 'Nemaguard' in root knot nematode resistance, 'Okinawa' seed exhibit reduced germination in the nursery row, presumably due to its early fruit maturity and insufficient seed development (Brooks and Olmo 1972). 'Nonpareil' is not used commercially as a rootstock, but was used in this study to represent a $X$. fastidiosa-susceptible almond rootstock. 'Sonora' is a widely planted scion and highly susceptible to ALSD (Cao et al. 2011; Sisterson et al. 2012). 'Sonora' budsticks were harvested from young trees at the SJVASC from which ALSD was absent. Emerged 
rootstock seedlings (planted in fall 2009) were grown until mid-June 2010. In mid-June, rootstock seedlings were 'T-budded' with 'Sonora' buds at approximately $15 \mathrm{~cm}$ above ground level. Two weeks after budding, rootstocks were pruned at $3 \mathrm{~cm}$ above the bud union. Any remaining rootstock buds located below the bud union were removed to avoid growth of rootstock suckers. Scion branches were not pruned during the study.

Inoculation of almond trees. X. fastidiosa subsp. fastidiosa (Strain M23) isolated from almonds (Chen et al. 2010) was grown in pure culture and mechanically inoculated (Hopkins 1988) to almond plants in late-July 2010. Inocula were prepared from 7- to 10 -day-old cultures as a turbid cell suspension of $\sim 10^{8}$ cells $/ \mathrm{ml}$ in water. A small drop of inoculum ( $7 \mu 1$ ) (or water, for negative controls) was placed at three different locations of the main stem of the scion (bottom, middle, and top); the stem was pierced with a needle through each drop. Each of the mechanical inoculation treatments (pathogen and water) were replicated 20 times per rootstock type. Trees were kept in field cages until January of the following year, and then were transplanted into an orchard at a spacing of $1.2 \times 4.6 \mathrm{~m}$ between trees and rows, respectively, using a randomized block design. The experimental field that received the trees was treated with InLine (Dow AgroSciences, Indianapolis, IN) soil fungicide and nematicide 3 months prior to planting. The fate of bacteria in planta after inoculations was evaluated for 4 years, based on symptom development, culturing, and PCR. In brief, leaf samples were transported to the laboratory and screened for presence of $X$. fastidiosa by PCR using primers RST31 and RST33 as described (Minsavage et al. 1994) and by culturing on PW medium (Davis et al. 1981).

Tree size and disease severity. Trunk circumference at $30 \mathrm{~cm}$ above the graft union was measured in February, August, and December each year and converted to trunk cross-sectional area $\left(\mathrm{cm}^{2}\right)$ prior to analysis. Presence of ALSD in plants was determined by the combination of symptom expression (e.g., marginal scorching on leaves) and identity confirmation of $X$. fastidiosa via PCR on bacteria cultured from plants. Disease severity was determined each year by a 5-min visual evaluation conducted in early October. During the 5-min observation, the percentage of symptomatic versus asymptomatic leaves in the unidimensional plane was estimated from each of four sides of the tree (north, south, east, and west). The average percentage of symptomatic leaves among the four sides of the tree was used in the analysis described below. Measurements of trunk circumference and disease severity were taken by the same observer throughout the study.

Statistical analysis. Trees belonging to the treatment group referred as $X$. fastidiosa-infected included those where presence of $X$. fastidiosa was confirmed on the first year after transplanting from the nursery to the orchard. Repeated measure ANOVA (SPSS 15.0, SPSS Inc., Chicago, IL) was used to evaluate effects of rootstock, inoculation treatment, block, and their interactions on trunk cross sectional area over 4 years. In addition, repeated measures analyses were performed individually for each rootstock type to assess i) effects of infection status on trunk cross sectional areas and ii) effects of rootstock type on symptom severity (e.g., percentage of symptomatic leaves). When results indicated a significant difference among treatments, treatment means were separated using Tukey's HSD test $(\alpha=0.05)$.

\section{Results}

During the nursery phase of almond tree production and transplant to the orchard, of the 20 replicates of each treatment $\times$ rootstock, a total of nine, three, five, and three water-inoculated (control) trees grafted on 'Nemaguard,' 'Nonpareil,' 'Okinawa,' and Y119 died, whereas 5, 6, 1, and $1 X$. fastidiosa-inoculated trees grafted on the respective rootstocks died. Among trees that survived the transplanting, a total of 9 of 15 trees grafted on 'Nemaguard' rootstocks were infected with $X$. fastidiosa after mechanical inoculation of bacteria. Among trees grafted on 'Nonpareil,' 'Okinawa,' and Y119 rootstocks, a total of 13 (of 14), 16 (of 19), and 13 (of 19) trees, respectively, were infected by X. fastidiosa after inoculations. Four years after being transplanted from the nursery to the orchard, measurements of trunk cross sectional areas of experimental trees were affected by rootstock type $(\mathrm{F}=18.095, \mathrm{df}=3,101, P<0.001)$ and inoculation treatment $(\mathrm{F}=10.976, \mathrm{df}=1,101, P=0.001)$, but not affected by block $(\mathrm{F}=2.106, \mathrm{df}=3,101, P=0.104)$ (Fig. 1). Trunk cross sectional area of trees on 'Nonpareil' rootstock were smaller than those on 'Nemaguard' $(P<0.001)$, 'Okinawa' $(P<0.001)$, and Y119 $(P<$ $0.001)$. There were no significant differences in trunk size among trees grafted on 'Nemaguard,' 'Okinawa,' and Y119.

Trunk cross sectional areas of $X$. fastidiosa-infected trees grafted on 'Nemaguard' and 'Nonpareil' rootstocks were significantly smaller than noninfected trees grafted on the respective rootstock ('Nemaguard': $\mathrm{F}=12.18$, df $=1,15, P=0.003$; 'Nonpareil': $\mathrm{F}=8.13$, df $=1,23, P=0.009$ ). The average \pm standard error (SE) trunk cross sectional areas of 5-year-old trees grafted on 'Nemaguard' were $85.28 \pm 6.75 \mathrm{~cm}^{2}$ and $118.56 \pm 6.18 \mathrm{~cm}^{2}$ for $X$. fastidiosa-infected and non-infected trees, respectively. Among the four rootstocks used in the study, trunk sizes of trees grafted on 'Nonpareil' rootstocks were the most affected by $X$. fastidiosa infection. The average trunk cross sectional areas of 5-year-old trees grafted on 'Nonpareil' were $38.79 \pm 4.72 \mathrm{~cm}^{2}$ and $66.83 \pm 5.93 \mathrm{~cm}^{2}$ for $X$. fastidios $a$-infected and noninfected trees, respectively. Trunk sizes of $X$. fastidiosa-infected trees grafted on 'Okinawa' and Y119 rootstocks did not differ from non-infected trees ('Okinawa': $\mathrm{F}=0.007$, df $=1,26, P=0.932$; Y119: $\mathrm{F}=2.241$, df $=1,25, P=0.444)$. The average trunk cross sectional areas of 5-year-old trees grafted on 'Okinawa' rootstocks were $92.18 \pm 7.17 \mathrm{~cm}^{2}$ and $93.55 \pm 4.13 \mathrm{~cm}^{2}$ for $X$. fastidiosa-infected and noninfected trees, respectively, and trees grafted on Y119 rootstocks were $99.21 \pm 14.40 \mathrm{~cm}^{2}$ and $114.16 \pm 6.61 \mathrm{~cm}^{2}$ for $X$. fastidios $a$-infected and noninfected trees, respectively (Fig. 1).

Among $X$. fastidiosa-infected trees, the numbers that remained asymptomatic (i.e., leaf scorching) during the 5-year study were three, zero, four, and one for trees grafted on 'Nemaguard,' 'Nonpareil,' 'Okinawa,' and Y119, respectively. None of the trees inoculated with water only (control) showed symptoms of ALSD or tested positive for presence of $X$. fastidiosa by culturing and PCR. X. fastidiosa infections and seasonal ALSD symptoms persisted throughout the study on all successfully inoculated trees grafted on 'Nonpareil' rootstocks. On average, disease severity increased steadily during the first three years and declined on the fourth year (Fig. 2). For trees grafted on 'Okinawa' and Y119 rootstocks, most X. fastidiosainfected trees remained infected and showed seasonal symptoms of ALSD throughout the study, except for two and three trees on 'Okinawa' and Y119 rootstocks, respectively, that did not show symptoms of ALSD and tested negative for presence of $X$. fastidiosa after the first year. Average disease severity of trees on 'Okinawa' and Y119 rootstocks declined after the first year and remained stable during the following three years (Fig. 2). All X. fastidiosa-infected trees grafted on 'Nemaguard' tested negative for presence of $X$. fastidiosa by culturing and PCR and did not display ALSD symptoms after the first (six trees) or second (three trees) year (Fig. 2). Overall ALSD severity was highest on trees grafted on 'Nonpareil' rootstock, intermediate on 'Okinawa' and Y119, and lowest on 'Nemaguard' ( $\mathrm{F}=5.741, \mathrm{df}=2,30, P=0.008)$. During the four yearly evaluations, disease severity of trees on 'Nonpareil' rootstocks were higher than on 'Okinawa' $(P=0.002)$ and Y119 $(P=0.01)$. There was no difference $(P=0.877)$ in disease severity between trees on 'Okinawa' and Y119 rootstocks.

\section{Discussion}

Almond trees infected by $X$. fastidiosa manifested two types of disease symptoms: leaf scorching and reduced growth. Among $X$. fastidiosa-infected trees, there was significant etiological heterogeneity with i) absence of leaf scorching symptoms in the presence of reduced growth, ii) presence of leaf scorching symptoms in the absence of reduced growth, and iii) severe leaf scorching and reduced growth. Specifically, remission of leaf scorching symptoms and apparent pathogen elimination indicated by lack of detection occurred within 2 years after orchard establishment in all $X$. fastidiosa-infected trees grafted on 'Nemaguard.' However, residual symptoms characterized by reduced growth persisted as trunks of water-inoculated (control) trees were consistently larger than trunks of trees that 
appeared to lose infections. One possible explanation for the reduced growth of disinfected trees compared with healthy trees was that $X$. fastidiosa effects on the tree vascular system such as occlusion of vessels with tyloses (Esau 1948) and/or changes in physical properties such as embolisms (Pérez-Donoso et al. 2016) may persist after disinfection. Alternatively, infection by $X$. fastidiosa may make trees more vulnerable to secondary infections that reduce growth compared with healthy trees.

In contrast with trees on 'Nemaguard' rootstock, symptoms of leaf scorching, reduced growth, and X. fastidiosa infection persisted throughout the study on all trees grafted on 'Nonpareil' rootstock, whereas remission of leaf scorching symptoms and apparent elimination of the pathogen occurred in only $30 \%$ of the X. fastidiosa-inoculated trees on 'Okinawa' and Y119 rootstocks. Despite the persistence of the pathogen and presence of mild leaf scorching symptoms throughout the study on most trees on 'Okinawa' and Y119 rootstocks, $X$. fastidiosa infections did not affect trunk size, which suggests that root vigor resulting from site conditions or rootstock tolerance to $X$. fastidiosa may have overridden the effects of infection on tree growth. A previous comparative study with Y119 rootstocks demonstrated it significantly enhanced first season growth as compared with 'Nemaguard' (Ledbetter and Sisterson 2008). In this study, effects of different rootstocks on ALSD intensity were tested against only one almond scion ('Sonora'). Given the different rootstock effects on disease phenotypes reported here and large cultivar effects on disease intensity observed among almond scions in other studies, it is expected that disease phenotypes would differ substantially among rootstock $\times$ scion combinations. For example, different

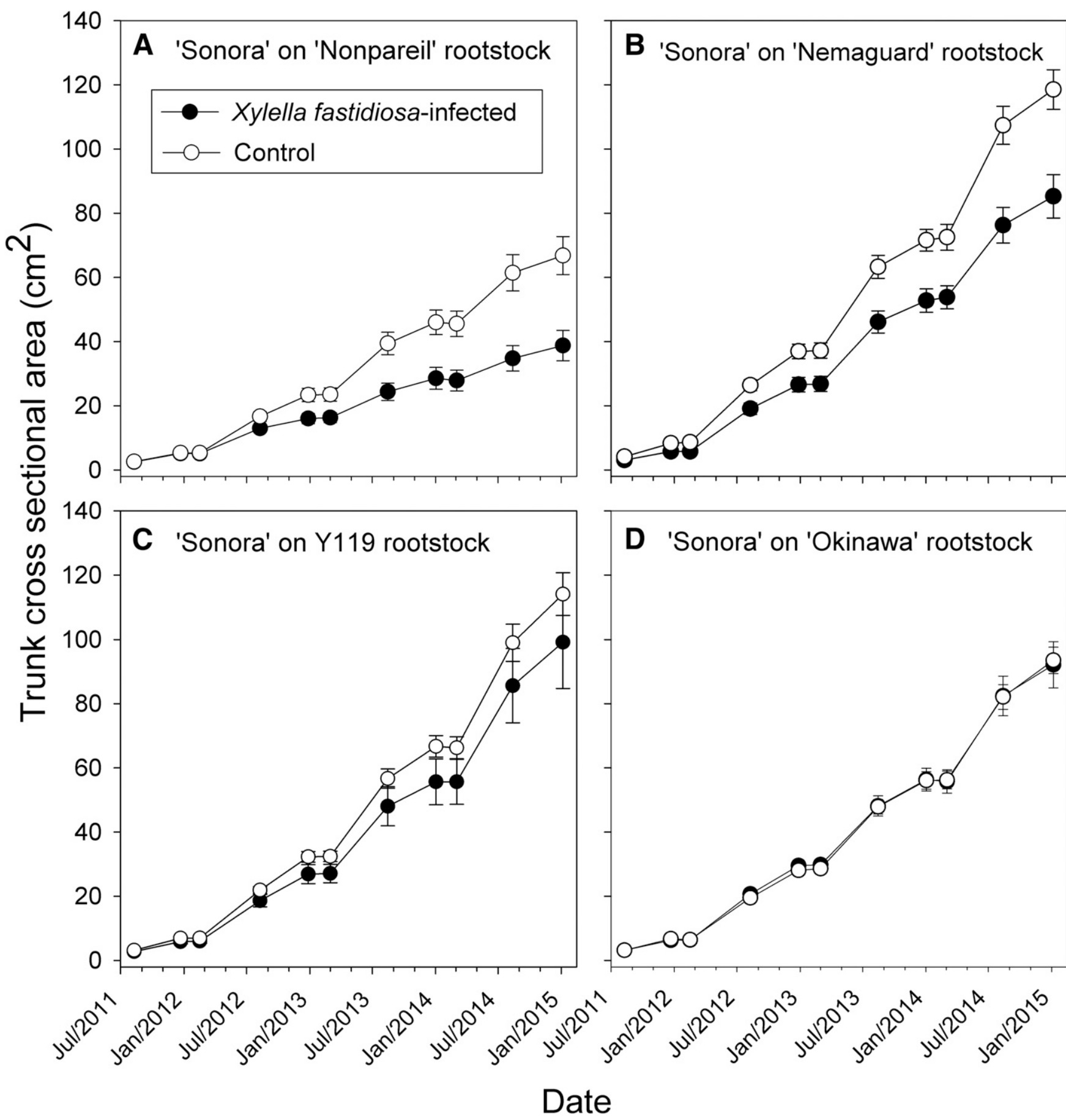

Fig. 1. Mean $( \pm \mathrm{SE})$ trunk cross-sectional area of almond (cv. Sonora) trees grafted on different rootstocks. Trees were inoculated with water (control) or Xylella fastidiosa subsp. fastidiosa (strain M23) in July 2010 during the period of almond nursery stock production. Measurements were taken at $30 \mathrm{~cm}$ above graft union. 
rootstock $\times$ scion combinations of grapevines affected population density of $X$. fastidiosa, concentration of phenolic compounds in plant tissue, and severity of Pierce's disease (Wallis et al. 2013). A comparison of chemical profiles of Citrus sinensis L. Osbeck, $C$. limonia Osbeck, and $C$. sinensis grafted on $C$. limonia revealed presence of a number of compounds that are not common in both species when grown alone (Ribeiro et al. 2008). Growth of $X$. fastidiosa in vitro was affected by some compounds (Ribeiro et al. 2008).

A difference in incidence of ALSD exists between surveys conducted in the early 1970s and more recent surveys. Although cultivar selection and planting location partially describe the heterogeneity in ALSD intensity during the history of almond production in California, a clear alternative has not been proposed. In the 1970s, the disease was widespread in California and reported to affect $50 \%$ of trees in some locations (Sanborn et al. 1974), whereas recent surveys showed incidence in affected orchards ranging from 0.08 to $17 \%$ (Cao et al. 2011; Daane et al. 2011; Sisterson et al. 2012). When first noted in California, ALSD was referred to as "golden death" due to the progression of symptoms toward tree death, an outcome that no longer occurs according to recent literature. Therefore, ALSD incidence reported in earlier surveys may have included (co-)infections by pathogens such as Phytophtora sp., which can quickly kill almond trees. Besides misdiagnosis, one factor that partially explains reduction in disease incidence during the last 40 years is orchard renewal with cultivars that are less susceptible to ALSD than cultivars of bearing trees during the 1970s. Another possible explanation was a rapid shift in the use of almond rootstocks that occurred in the late 1960s and early 1970s. 'Nemaguard' was developed at USDA stations in Fort Valley, GA and Fresno, CA and released in 1959 as a rootstock for almond and stone fruits due to resistance to nematodes and vigor of top growth (Weinberger 1959). By 1968, the demand for 'Nemaguard' as almond rootstock in California had reached 90 to $100 \%$ (Weinberger 1968) and today a majority of bearing almond trees in California are grown on 'Nemaguard.' Because it is resistant to X. fastidiosa, this rootstock prevent infection of almond nursery stock under field conditions during the growth period prior to budding (Krugner et al. 2012), as well as promote an apparent complete pathogen elimination and remission of leaf scorching symptoms, likely due to containment of bacterial populations to above ground tree parts, increasing the intensity of the winter curing phenomenon and decreasing probabilities of secondary pathogen spread.

The combination of disease attributes (e.g., incidence, severity) used in this study showed that a $X$. fastidiosa-resistant trait in the rootstock can be valuable for maintaining low incidence of ALSD in California. However, screening large numbers of candidate rootstocks

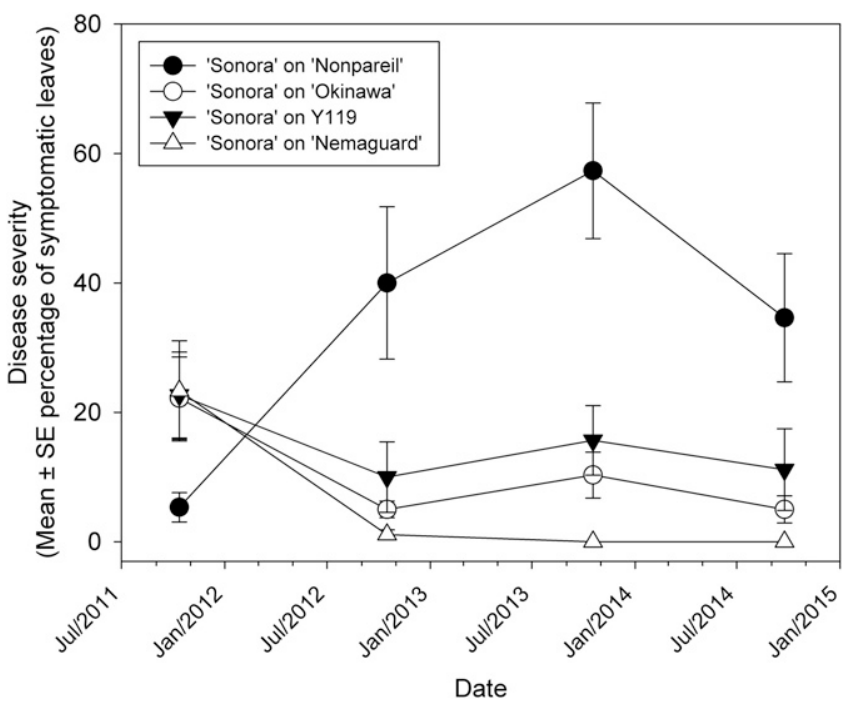

Fig. 2. Mean $( \pm S E)$ percentage of symptomatic leaves among four sides of almond (cv. Sonora) trees grafted on different rootstocks. Disease severity was determined by a 5-min visual evaluation of symptomatic versus asymptomatic leaves. for resistance to the full spectrum of almond pathogens in a broad range of environmental conditions is labor intensive. A number of rootstocks have been made available to help mitigate problems associated with soil properties, diseases, and nematodes for specific almond production sites. Research on rootstock improvement continues to make new rootstocks available, including several peach $\times$ almond (PEAL) hybrids (Duncan et al. 2009) that combine desirable traits of peach and almond such as improved tree anchorage and resistance to soil pathogens. A promising rootstock lineage of PEAL hybrid plants $(P$. persica $\times P$. dulcis) developed by the plant breeding program at the USDA in Parlier, CA, has shown resistance to $X$. fastidiosa and ALSD (Ledbetter and Rogers 2009). In contrast, $X$. fastidiosa grew to high population densities in another PEAL hybrid lineage $(P$. webbii (Spach) Vierhapper $\times P$. persica), indicating differences in inheritance of the genetic basis of resistance/susceptibility to $X$. fastidiosa (Rogers and Ledbetter 2015). While breeding of 'Nemaguard' with the intention of providing resistance to nematodes unintentionally provided resistance to $X$. fastidiosa, modern molecular tools should be made available to identify rapid screening methods for classification of accessions into distinct subgroups.

Selection of a rootstock for establishment of an orchard depends on conditions at a specific site such as chemical and physical properties of the soil, nematode pressure, pathogens, anchorage, and drainage. Although trunk cross sectional areas recorded in this study did not differ among rootstocks 'Nemaguard,' 'Okinawa,' and Y119, further studies are needed to evaluate the performance of these rootstocks under different soil conditions and disease pressure. The broad goal of this study was to elucidate effects of $X$. fastidiosa infection on tree growth during orchard establishment. In mature almond orchards, consistent yield losses were reported from evaluations of $X$. fastidiosa-infected versus noninfected trees (Sisterson et al. 2012). However, in areas affected by ALSD, the risk of secondary spread of the pathogen is low. As a result, decisions to replace infected trees with replants depend on orchard age, with replanting being warranted in young orchards but not in mature orchards (Sisterson et al. 2008). As almond trees in commercial orchards in California are replaced approximately every 20 years, additional research has been needed to evaluate the effects of exclusion and duration of $X$. fastidiosa infections on young tree performance and subsequent effects on tree vigor. Results showed that, depending on rootstock type, $X$. fastidiosa can affect trunk size in a relatively short period and/or persist for years as trees grow.

\section{Acknowledgments}

We thank Theresa de la Torre, Aaron J. Salyers, Matthew Escoto, and Melissa Fujioka for technical assistance. This work was funded by USDA-ARS appropriated project \# 2034-22000-010-00D.

\section{Literature Cited}

Boyhan, G. E., Abrahams, B. R., and Norton, J. D. 1996. Budding method affects transmission of Xylella fastidiosa in plum. HortScience 31:89-90.

Brooks, R. M., and Olmo, H. P. 1972. Register of new fruit \& nut varieties, 2nd Ed. Univeristy of California Press, Berkeley.

Cao, T., Connell, J. H., Wilhelm, M., and Kirkpatrick, B. C. 2011. Influence of inoculation date on the colonization of Xylella fastidiosa and the persistence of almond leaf scorch disease among almond cultivars. Plant Dis. 95:158-165.

Cao, T., DeJong, T. M., and Kirkpatrick, B. C. 2013. Almond leaf scorch disease development on almond branches high-grafted on peach rootstock. Plant Dis. 97:277-281.

CDFA. 2015. 2014 California Almond Acreage Report. Online: http://www. nass.usda.gov/Statistics_by_State/California/Publications/Fruits_and_Nuts/ 201504almac.pdf.

Chen, J., Xie, G., Han, S., Chertkov, O., Sims, D., and Civerolo, E. L. 2010. Whole genome sequences of two Xylella fastidiosa strains (M12 and M23) causing almond leaf scorch disease in California. J. Bacteriol. 192:4534.

Daane, K. M., Wistrom, C. M., Shapland, E. B., and Sisterson, M. S. 2011. Seasonal abundance of Draeculacephala minerva and other Xylella fastidiosa vectors in California almond orchards and vineyards. J. Econ. Entomol. 104: 367-374.

Davis, M. J., French, W. J., and Schaad, N. W. 1981. Axenic culture of the bacteria associated with phony disease of peach and plum leaf scald. Curr. Microbiol. 6:309-314.

Davis, M. J., Purcell, A. H., and Thompson, S. V. 1978. Pierce's disease of grapevines: isolation of the causal bacterium. Science 199:75-77. 
Davis, M. J., Thomson, S. V., and Purcell, A. H. 1980. Etiological role of a xylemlimited bacterium causing Pierce's disease in almond leaf scorch. Phytopathology 70:472-475.

Duncan, R., Connell, J., and Edstrom, J. 2009. Field evaluation of almond rootstocks. Pages 55-63 in: Proceedings, Almond Board of California. 37th Almond Industry Conference, Dec. 9-10, Modesto, CA.

Esau, K. 1948. Anatomic effects of the viruses of Pierce's disease and phony peach. Hilgardia 18:423-482.

Feil, H., and Purcell, A. H. 2001. Temperature-dependent growth and survival of Xylella fastidiosa in vitro and in potted grapevines. Plant Dis. 85:1230-1234.

Hopkins, D. L. 1988. Xylella fastidiosa and other fastidious bacteria of uncertain affiliation. Pages 95-103 in: Laboratory Guide for Identification of Plant Pathogenic Bacteria, 2nd Ed., N. W. Schaad, ed. American Phytopathological Society, St. Paul, MN.

Hutchins, L. M., Cochran, L. C., Turner, W. F., and Weinberger, J. H. 1953. Transmission of phony disease virus from tops of certain affected peach and plum trees. Phytopathology 43:691-696.

Krugner, R., Ledbetter, C. A., Chen, J., and Shrestha, A. 2012. Phenology of Xylella fastidiosa and its vector around California almond nurseries: an assessment of plant vulnerability to almond leaf scorch disease. Plant Dis. 96: 1488-1494.

Ledbetter, C. A., Chen, J., Livingston, S., and Groves, R. L. 2009. Winter curing of Prunus dulcis cv 'Butte,' P. webbii and their interspecific hybrid in response to Xylella fastidiosa infections. Euphytica 169:113-122.

Ledbetter, C. A., and Rogers, E. E. 2009. Differential susceptibility of Prunus germplasm (subgenus Amygdalus) to a California isolate of Xylella fastidiosa. HortScience 44:1928-1931.

Ledbetter, C. A., and Sisterson, M. S. 2008. Advanced generation peach-almond hybrids as seedling rootstocks for almond: first year growth and potential pollenizers for hybrid seed production. Euphytica 160:259-266.

Lieth, J. H., Meyer, M. M., Yeo, K.-H., and Kirkpatrick, B. C. 2011. Modelling cold curing of Pierce's disease in Vitis vinifera 'Pinot Noir' and 'Cabernet Sauvingnon' in California. Phytopathology 101:1492-1500.

Minsavage, G. V., Thompson, C. M., Hopkins, D. L., Leite, R. M. V. B. C., and Stall, R. E. 1994. Development of a polymerase chain reaction protocol for detection of Xylella fastidiosa in plant tissue. Phytopathology 84:456-461.
Mircetich, S. M., Lowe, S. K., Moller, W. J., and Nyland, G. 1976. Etiology of almond leaf scorch disease and transmission of the causal agent. Phytopathology 66:17-24.

Pérez-Donoso, A. G., Lenhof, J. J., Pinney, K., and Labavitch, J. M. 2016. Vesse embolism and tyloses in early stages of Pierce's disease. Aust. J. Grape Wine Res. 22:81-86

Purcell, A. H. 1980. Almond leaf scorch: leafhopper and spittlebug vectors. J. Econ. Entomol. 73:834-838.

Reighard, G. L. and Loreti, F. 2008. Chapter 8: Rootstock Development. Pages 193-215 in: The Peach: Botany, Production and Uses. D. R. Layne and D. Bassi, eds. CAB International publishers, Wallingford, UK.

Ribeiro, A. B., Abdelnur, P. V., Garcia, C. F., Belini, A., Severino, V. G. P., da Silva, M. F. D. G. F., Fernandes, J. B., Vieira, P. C., de Carvalho, S. A., de Souza, A. A., and Machado, M. 2008. Chemical characterization of Citrus sinensis grafted on $C$. limonia and the effects of some isolated compounds on the growth of Xylella fastidiosa. J. Agric. Food Chem. 56:7815-7822.

Rogers, E. E., and Ledbetter, C. A. 2015. Susceptibility to Xylella fastidiosa in a first-generation hybrid from a non-traditional peach-almond cross. HortScience 50:337-340.

Sanborn, R. R., Mircetich, S. M., Nyland, G., and Moller, W. J. 1974. "Golden death": A new leaf scorch threat to almond growers. Calif. Agric. 28:4-5.

Sisterson, M. S., Chen, J., Viveros, M. A., Civerolo, E. L., Ledbetter, C., and Groves, R. L. 2008. Effects of almond leaf scorch disease on almond yield: Implications for management. Plant Dis. 92:409-414.

Sisterson, M. S., Ledbetter, C. A., Chen, J., Higbee, B. S., Groves, R. L., and Daane, K. M. 2012. Management of almond leaf scorch disease: Long-term data on yield, tree vitality, and disease progress. Plant Dis. 96:1037-1044

Wallis, C. M., Wallingford, A. K., and Chen, J. 2013. Grapevine rootstocks effects on scion sap phenolic levels, resistance to Xylella fastidiosa infection, and progression of Pierce's disease. Front. Plant Sci. 4:1-9.

Weinberger, J. H. 1959. Notice to nurseryman on a new nematode resistant peach rootstock. USDA-Agricultural Research Service variety release notice.

Weinberger, J. H. 1968. Monthly report on stone fruit project. USDA-Agricultural Research Service, Fresno, CA.

Wilhelm, M., Brodbeck, B. V., Andersen, P. C., Kasun, G. W., and Kirkpatrick, B. C. 2011. Analysis of xylem fluid components in almond cultivars differing in resistance to almond leaf scorch disease. Plant Dis. 95:166-172. 